\title{
Keeping Justice (Largely) Out of Charity: Pluralism and the Division of Labour between Charitable Organisations and the State
}

\author{
Daniel Halliday and Matthew Harding* \\ Forthcoming in Legal Theory \\ Penultimate Draft: Please use published version for any quoting/citing
}

\begin{abstract}
The pursuit of justice can be pursued by the state, or through voluntary charity. Appreciation of this fact has motivated discussion of the appropriate division of labour between government and charitable agencies. This paper seeks to contribute to this debate by developing a positive account of the moral foundations of the charity sector, which has so far been absent from influential discussions of this division of labour. The account given here is grounded in a legal conception of charity, as a set of subsidies and privileges designed to cultivate a wide variety of activities aimed at enhancing civic virtue and autonomy. Among other things, this implies that a charity sector oriented largely around the pursuit of justice will come at a moral cost to a liberal society, at least when the state is in a position to take the greater share of the responsibility. So, a positive account of charity provides at least a pro tanto reason for preferring a division of labour in which the state takes a greater share of the responsibility for pursuing justice. As well as developing and defending this conception in its own right, we apply it in offering some criticisms and enhancements of existing views about the division of labour.
\end{abstract}

\section{Introduction: Motivating a Division of Labour}

In 2014, a British charity, Pancreatic Cancer Action, sought to raise awareness of their cause via a printed and online ad campaign. One of their ads depicted a female pancreatic cancer patient, alongside a slogan that read "I wish I had breast cancer". At 3\%, the survival rate for pancreatic cancer lies below that of any other cancer. Breast cancer's survival rate, at $85 \%$, is among the highest. ${ }^{1}$ Pancreatic Cancer Action explained that the point of their campaign was to raise awareness of a relatively unknown cancer, and that they were drawing inspiration from past campaigns that had arguably contributed to recent success in raising the breast cancer survival rate. Nevertheless, the campaign was widely criticised, with reactions ranging from accusations of insensitivity to death threats aimed at the patient whose photograph was used. ${ }^{2}$

Many of the goals pursued by specific charitable organisations could, in principle, be pursued through the government's institutions instead. Importantly, this would mean their being pursued in a different way. While charities rely on eliciting the voluntary supply of funds

\footnotetext{
* Daniel Halliday is associate professor in philosophy, and Matthew Harding is a professor of law, at the University of Melbourne. Our sincere thanks to Jill McFadyean for her invaluable assistance. Thanks are due to audiences at the Julius Stone Institute, University of Sydney Law School, and an applied ethics seminar at University of Melbourne. We also thank Peter Singer for comments on an earlier draft.

${ }^{1}$ These figures represent survival rates at 5 years post-diagnosis. Up to date and detailed figures can be found at https://www.cancerresearchuk.org/health-professional/cancer-statistics/survival (accessed 06.11.2020).

${ }^{2}$ A quick internet search will take the reader to plenty of news coverage, in spite of the campaign having closed some years ago. Particularly detailed is https://advertising-health.com/massive-debate-wish-breast-cancercampaign/ (accessed 06.11.20).
} 
to pursue their goals, the state can source funds coercively, through taxation, and then allocate the revenues to programs similar to those conducted by charities. The state's powers (idealising somewhat) allow it to pursue any such goals without resorting to eye-catching and often provocative advertisements of the sort we've just highlighted. These considerations are among those that motivate philosophical inquiry into what has been described as the division of labour' between charitable organisations and the state. ${ }^{3}$ Our task is to look into some of the reasons for preferring the state mechanism. Some of what we say will draw on the concerns instantiated in reactions to the pancreatic cancer ad. But we will attach more fundamental significance to general considerations about what the legal institution of charity is really for. Such considerations tell us not just what charity should be expected to do, but also when too much, or the wrong thing, is being asked of it.

A further motivational point concerns the way in which charity is discussed in academic disciplines over recent decades. First, we will say something about moral and political philosophy. Currently, philosophers are involved in well-developed exchanges about how much one should give to charity, how one should choose between charities, and how one can organize one's life so as to do the most good, largely through enabling greater amounts of charitable giving. ${ }^{4}$ This sometimes proceeds with little reflection as to what the charity sector is for, beyond the broad idea that charitable organisations provide a mechanism for 'doing good'. Implicit in much of this work is that the mechanism of charity is merely an alternative to the institutions of the state, such that state and charity are just different ways of getting the same job done. While the proponents of charitable giving face some forceful criticisms from other philosophers, these do not draw on any foundational accounts of the charity sector either. ${ }^{5}$ Current socio-political trends are somewhat parallel in treating the state and charitable organisations as somewhat fungible with respect to each other. Charities abound that purport to have a 'social justice' mission. Governments increasingly prefer indirect models of provision, which also helps to explain why many charities receive much of their funding from the state and make strategic and operational decisions with state priorities and preferences in mind.

The habit of viewing charities and the state as interchangeable is not confined to philosophical analysis. It also characterises the voluminous literature on charities produced by

\footnotetext{
${ }^{3}$ In using this terminology we follow Chiara Cordelli, The Institutional Division of Labor and the Egalitarian Obligations of Nonprofits, 20 The Journal of Political Philosophy 131 (2012).

${ }^{4}$ Here we have in mind (especially) the 'effective altruism' movement, at least as it is represented in philosophical work. This project builds on the earlier work of Peter Singer, Famine, Affluence and Morality, 1 Philosophy \& Public Affairs 229 (1972). A contemporary philosophical proponent is William MacAskill, Doing Good Better: Effective Altruism and a Radical New Way to Make a Difference (2015).

${ }^{5}$ Effective altruists have been accused of naivety about the effectiveness of charitable organizations at addressing goals such as global poverty relief (Leif Wenar, Poverty is No Pond: Challenges for the Affluent, in Giving Well: The Ethics of Philanthropy 104 (P Illingworth, T Pogge \& L Wenar eds., 2011). Other critics are skeptical about the methodology of focusing on what individual agents can do in isolation, in isolation from efficacious macrolevel forces (David Schmidtz, Islands in a Sea of Obligation: Limits of the Duty to Rescue 19 Law \& Philosophy 683 (2000). Others worry that such a focus ends up being an implicit apology for the status quo injustices that have created the problems that the movement aims to solve (Amia Srinivasan, Stop the Robot Apocalypse, London Review of Books: http://www.lrb.co.uk/v37/n18/amia-srinivasan/stop-the-robot-apocalypse (accessed 10.10.2015)). Since these objections neither affirm nor deny any account of the foundations of charity, we do not take a stand on them here. For a general overview, though, see Jason Gabriel, Effective Altruism and its Critics 34 Journal of Applied Philosophy 457 (2017).
} 
economists. ${ }^{6}$ Some of the seminal contributions to this literature view the charity sector as a solution to the problem of 'state failure' in the provision of goods and services; ${ }^{7}$ others talk in terms of 'market failure' as well. ${ }^{8}$ Such accounts identify the point and purpose of charities with reference to what the state or the market might do in theory, but cannot or will not do in practice. On this view, charities do not have distinctive value in the absence of state or market failures. Some have noticed this, and sought to develop theoretical accounts of the charity sector that identify its value irrespective of state or market failures. ${ }^{9}$ But such accounts are not numerous, and there is more work to be done on the question whether we should value a charity sector for reasons that do not relate to the shortcomings of the state or the market as a provider of goods and services.

Here is the paper's main argument in brief: What justifies the existence of charitable organizations, and thereby defines the basic elements of such organizations, is that certain activities ought to be facilitated by the state even though there are reasons against having the state take primary responsibility for providing them directly through its own institutions. This is because, while the pursuit of justice is undoubtedly important, there are nevertheless reasons to believe that certain institutions are justified primarily as a means to pursuing other goals. Accordingly, there are reasons to allow such institutions to pursue non-justice goals to a large extent. The charity sector represents an effort by the liberal state to protect, but not to directly influence, a heterogeneous body of activities by its citizens aimed at enhancing their civic virtue and promoting their autonomy.

Some activities contribute to individuals' exercise and cultivation of autonomy, but remain unfeasible, or unduly held back, without a degree of state support. Some of these activities, such as receiving an education, have enough moral significance to warrant support by the state's use of coercion, as reflected in the use of taxation to fund schooling and laws requiring the attendance of children. Some activities, however, are not so important as to justify the use of state coercion. Instead, these activities should receive a weaker degree of support aimed at reducing their running costs and making it easier for them to attract donations from individual citizens. This is what accounts for the existence of the legal category of charity, and the various laws that provide this sort of protection for charitable organizations. From these foundations, we can conclude two things about the division of labour in respect of charity and justice. First, there is a genuine danger that the autonomy-enhancing potential of the charity sector will be degraded if the work of the state is 'outsourced' to it. This risks crowding out the sort of activities that the charity sector is really for, in favour of activities whose greater moral urgency means they should remain the state's responsibility. Second, we will argue that understanding the foundations of charity in this way also helps enhance some existing accounts of the

\footnotetext{
${ }^{6}$ An outstanding conspectus of such literature may be found in Richard Steinberg, Economic Theories of Nonprofit Organizations, in The Nonprofit Sector: A Research Handbook 117 ( $2^{\text {nd }}$ ed, WW Powell and R Steinberg eds., 2006), and Richard Steinberg \& Brian Galle, A Law and Economics Perspective on Nonprofit Organizations, in Research Handbook of Not-for-Profit Law 16 (M Harding ed., 2018).

${ }^{7}$ See, eg, Burton Weisbrod, Toward a Theory of the Voluntary Nonprofit Sector in a Three-Sector Economy, in Altruism, Morality, and Economic Theory 171 (ES Phelps ed., 1975).

${ }^{8}$ See, eg, Henry Hansmann, The Role of Nonprofit Enterprise 89 Yale Law Journal 835 (1980).

${ }^{9}$ For two recent examples: Matthew Harding, Charity Law and the Liberal State (2014); Rob Atkinson, A Primer on the Neo-Classical Republican Theory of the Nonprofit Sector (and the other three sectors too), in Research Handbook on Not-for-Profit Law 48 (M Harding ed., 2018).
} 
advantages of state coercion with respect to the pursuit of some specific goals associated with the requirements of justice. In more metaphorical terms, the protections of charity law acknowledge a sort of 'middle ground' between the pursuit of morally neutral goals that happen to be commercially viable and the pursuit of justice. In other words, charity is primarily for something other than the pursuit of justice, even though the pursuit of justice might be included among the various things that charitable organizations do, in ways that supplement the efforts of the state.

This view is a version of what Robert Reich has recently called pluralism about the moral purpose of charity. Reich's definition of pluralism is best captured in the following remarks:

The basic idea is that a tax incentive to make donations should not be justified on the basis of assessing the discrete social goods, or outputs, of the various non-profit organizations funded through these donations. Instead, a tax incentive is justified for its role in stimulating or amplifying the voice of citizens in the production of a diverse, decentralized, and pluralistic associational sector, which is itself normatively desirable because it is considered to be a bedrock of a flourishing democracy. ${ }^{10}$

Reich's words make it clear that he wants to undermine the narrative of merely 'doing good'11, as per the motivation we highlighted just above when commenting on current debates in philosophy. Here we follow his lead. Although we want to retain Reich's emphasis on how the creation of a charity sector can be justified by the distinctive sorts of opportunities it can create for citizens, our arguments differ somewhat (though may complement) those that Reich goes on to develop. ${ }^{12}$

Pluralism of this sort has various theoretical advantages. First, it provides a principled explanation for why justice should be seen as largely the responsibility of the state, without taking the rather counter-intuitive view that the pursuit of justice should be wholly purged from the charity sector. (The reason for this is that the pursuit of justice remains one way in which citizens can cultivate virtue and autonomy.) Second, it lends force to recent concerns about 'big philanthropy' that are typically expressed in terms of plutocracy, but which benefit from some reference to what is distinctive about a plutocratic worry applied within the charity sector as opposed to worries about plutocracy with respect to other agencies and institutions. Third, pluralism about charity provides a nice way of showing how a liberal state can be concerned to facilitate the development of its citizens without becoming intrusive or perfectionist, or falling foul of other ills of centralized power.

Before we proceed, some background points. First, we want to disambiguate the idea that justice is something 'pursued'. Really there are at least two dimensions relevant here, one

\footnotetext{
${ }^{10}$ Robert Reich, Just Giving: Why Philanthrophy is Failing Democracy and How It Can Do Better (2018); for the bulk of Reich's discussion of pluralism see 128-133; 153-155.

${ }^{11}$ See the remarks at ibid 12, on the difference between political and non-political approaches in philosophy. A similar point is made by Emma Saunders-Hastings, Plutocratic Philanthropy 18 Journal of Politics 149 (2018).

12 Reich makes two key arguments that we do not seek to discuss. These include the idea that charitable foundations decentralize decision-making in ways that provide an alternative to "government orthodoxy" in the provision of goods (supra note 10, at 130), and that charities benefit from a long time horizon not shared by governments of the democratic sort whose policies are constrained by a need to get re-elected (supra note 10, at 152). Reich's arguments rely on a substantive view about the limits of government agency. While we find his position plausible and have learned from it in developing our own, we note that it differs in that the case for a charity sector does not draw wholly on non-comparative considerations about what charitable organizations are for, whereas ours does.
} 
pertaining to the funding of justice and the other to what we might call its delivery. These can be carried out by state and charitable agencies in a variety of combinations. The labour can be divided at the level of funding, as per the distinction, already mentioned, between coercive taxation and voluntary donation. But the labour can also be divided according to how these revenues are put to work: Charities can run their own development programmes, conduct their own biomedical research and so on, as can governments. Funding and delivery may be subject to independent divisions of labour. Government might be the dominant agent when it comes to funding justice, but, at least in principle, charity could take care of the delivery entirely on its own. Careful work is required when theorising about how the labour should be divided at each level. On the whole our attention is more focused on the funding of justice than on its delivery. (To save words, however, we will sometimes continue to speak of the 'pursuit' of justice when the distinction between these elements of its pursuit is not crucial.)

We should also say something more about what we mean by 'justice'. Here, we make only the relatively weak assumption that justice requires some degree of material redistribution from better-off to worse-off members of society, particularly when worse-off members of society struggle to meet their basic needs. We take this claim to be compatible with most contemporary conceptions of justice. ${ }^{13}$ Plenty of contemporary conceptions do, of course, include much stronger requirements than just ensuring that all citizens can satisfy their basic needs. The number of people currently struggling to meet their basic needs is enough to present a formidable task to charitable organisations attempting to fund and/or deliver justice without the state. These claims are even more plausible if one accepts that the requirements of justice extend across international borders, such that wealthy states owe substantial duties of aid to the global poor. ${ }^{14}$ This weak view of justice is enough to motivate our project. Any stronger view of what justice requires either preserves or strengthens this motivation.

'Justice' is often taken to refer to a virtue, rather than to requirements to bring about certain states of affairs. At times we will refer to justice in this other sense. We aim to build on the thought that a person who pursues justice has a disposition to value justice as a state of affairs, and has an associated disposition to orient their choice and action to bringing that state of affairs about. A person without such a disposition might engage with justice in some way they might, for example, reflect on the demands of justice in a theoretical rather than a practical way, or act in ways that happen to coincide with the realisation of justice ${ }^{15}$ - but they could not reasonably be viewed as pursuing justice in the sense of being moved to action with an eye to bringing justice about. The pursuit of justice and what Rawls called the "sense of justice" are a package deal. ${ }^{16}$ One might suspect, offhand, that such a disposition should make an individual supportive of the pursuit of justice through any mechanism. An understanding of justice as a

\footnotetext{
${ }^{13}$ We think that this approximates the idea of distributive justice that emerged in the nineteenth century, where justice is some set of requirements associated with distributing scarce resources, and where disagreement is largely about the precise details as to the reasons why, and as to whether the requirements of justice are any stronger. See Samuel Fleischacker, A Short History of Distributive Justice (2004).

${ }^{14}$ We leave it open whether such border-crossing requirements differ in some respects from the requirements of traditional domestic justice. On this, compare Thomas Nagel, The Problem of Global Justice 33 Philosophy \& Public Affairs 113 (2005) with Joshua Cohen \& Charles Sabel, Extra Republicam Nulla Justitia? 34 Philosophy \& Public Affairs 147 (2006).

${ }^{15}$ Indeed, in some circumstances, this may be the surest way to achieve justice. See John Gardner, The Virtue of Charity and its Foils, in Foundations of Charity 1 (C Mitchell \& S Moody eds., 2000) at 2-3.

${ }^{16}$ John Rawls, A Theory of Justice (revised ed., 1999) at Ch.8.
} 
virtue, alongside an understanding of justice as a state of affairs, is, however, key to our argument against the charitable delivery of justice.

\section{The Liberal Foundations of Charity Law}

It should go without saying that the existence of charitable organizations is not simply some spontaneous occurrence. Charities exist because of a political decision to create a legal category of organization with its own special status and protections, and on the basis of some moralized set of foundations accounting for why such a category should be recognized. This in itself strongly suggests that philosophical thinking about the division of labour should work with some positive account of what charity is for.

When speaking of the foundations of charity in this legally-oriented way, we mean something quite specific: A certain category of private activity whose boundaries are generally well defined by law, and which is basically institutionalized. In this way, our concept of charity differs from older concepts of charity, which include any activity of private, voluntary giving, of a sort that needn't be subject to legal protections, or even institutionalized at all. There are various differences between the legal and traditional concepts of charity. First, the legalized concept is not restricted to activities that involve giving to the needy, and, given the sort of organizations that often qualify for charitable status, may involve activities not necessarily construed as primarily altruistic. (We will come back to this point, as it eventually proves instructive.) Second, the traditional concept has its roots in theological writings that were produced before modern conceptions of justice, or indeed modern state institutions, were developed. The foundations of charitable activity in this sense are, accordingly, entrenched in ideas about how voluntary giving pleases God and/or improves one's wellbeing in some spiritual way. While this view of charity does suggest one way in which the pursuit of justice might fall somewhat on voluntary acts by private individuals rather than the state, it is hard to mount a secular defence of such foundations. ${ }^{17}$

This difficulty aside, the legalized concept of charity is the right one to work with when studying the division of labour. There are at least three reasons for this. First, legally defined charities are usually what people are talking about when they speak of making charitable donations - people are almost always referring to donations made to some organization that is legally registered as a charity, even if it passes on such donations to non-charities (such as needy individuals). While there is certainly such a thing as spontaneous, non-institutionalized, private giving, it is not on a large scale: If justice were to be successfully pursued via charity, this would surely have to involve institutionalized charitable organizations. Second, since the old theological conceptions of charity's foundations were developed before the emergence of large state institutions, such conceptions were formulated at a time when the division of labour question was not salient. In addition, they somewhat predate the modern concept of justice itself, meaning that the traditional concept of charity arguably serves as a prototype concept of

\footnotetext{
${ }^{17}$ Kymlicka develops this point at considerable length. His main claim is that secularizing the theological contention that charity improves one's character would be to turn moral foundations into prudential foundations (Will Kymlicka, Altruism in Philosophical and Ethical Traditions: Two Views, in Between State and Market: Essays on Charities Law and Policies in Canada 87 (J Philips, B Chapman \& D Stevens eds, 2001), at 112-113). This claim might be resisted, we think, if engaging in charity is about stimulating the virtues (see main text below).
} 
justice, rather than as the contrasting concept that it has since come to be. ${ }^{18}$ These two considerations are at least implicitly assumed in the literature with which we engage in this paper, and we state them to make them more explicit rather than in an attempt at originality. Third, however, the history of charity law from the period after the emergence of more substantial state institutions actually does supply a set of secular foundations for charitable activity. These can be applied to the question of how much the pursuit of justice might be left to charities rather than the state. Their application allows us to draw conclusions about what the charitable delivery of justice might cost the charity sector. An inquiry oriented in this way might seek to identify values associated with charitable organisations, and then think about how and to what extent those values are likely to be suppressed or compromised where the charity sector strives in its activities to deliver justice. This third point is less often appreciated and in drawing attention to the legal history we do seek to make a more original point, so far as prevailing philosophical discussions go, in the defence of pluralism. This will be our focus in this section.

When thinking about the moral foundations of institutionalized charity, it is still intuitive to suggest the whole point of charity is for doing good. This needn't undermine a distinction between charity and justice. Some of the good outcomes pursued by charitable organizations might coincide with what's required by justice, but this is not a necessary condition of calling them good. This is reflected in the fact that in most jurisdictions, charities usually earn their legal status only where their purposes stand to produce 'public benefit'. ${ }^{19}$ The relevant measure of such benefit is not understood narrowly as a response to the demands of justice, but rather as goods to be shared with the wider community. Examples may include such goods as a public museum or free internet access. One way of mounting an argument against the charitable delivery of justice might be to argue that at least some of the good outcomes that charities deliver are likely to be compromised or threatened in circumstances where charities deliver justice.

Importantly, however, the charity sector doesn't just produce good outcomes - it also produces them in particular ways. The voluntariness of charity makes it possible for people to act autonomously, by forming associations and choosing how to conduct them for the public benefit. In societies where citizens have a plurality of conceptions of the good, the charity sector has proven a very popular site for free association and autonomous action for a multiplicity of ends. ${ }^{20}$ In part because of this, the charity sector has also proven well suited to fostering the development and expression of a number of virtues, including loyalty, conscientiousness, humanity, mercy and public-spiritedness. Think, for example, of the churchgoer who proves loyal through her diligent care for sick or lonely members of her congregation. Or the staff of a homeless shelter who display charity to the needy and desperate night after night. Or the board of an opera house who manifest a visionary public-spiritedness

\footnotetext{
${ }^{18}$ Here we follow Kymlicka: ibid, at 113 . For a longer discussion of the history of the justice/charity distinction, see Fleischacker, supra note 13.

19 For a helpful summary of the legal requirements in a range of countries: Charity Law: Jurisdictional Comparisons (Anne-Marie Piper ed., 2012).

${ }^{20}$ The value of these aspects of the charity sector can also ground opposition to public-private partnerships between state agencies and charitable organisations: see Chiara Cordelli, How Privatization Threatens the Private 16 Critical Review of International Social and Political Philosophy 65 (2013).
} 
in their choice of programmes. The expression of such virtues helps to constitute just some of the modes by which the charity sector produces its good outcomes. ${ }^{21}$

Where the charity sector delivers justice, this might undermine or threaten one or more of the opportunities for manifesting virtue bound up with the charity sector. This may sound odd: How could pursuing justice not be virtuous? The answer lies in how to understand the virtue of justice as it relates to the sort of agency that seeks to bring about just states of affairs, and how the virtue of justice is not the only virtue whose exercise a liberal state should aim to facilitate in its citizens. Generally, where a person's mandate or task is to bring about justice as a state of affairs, the virtue of justice is the appropriate virtue to cultivate when thinking about what is to be done. A person who acts loyally or mercifully in circumstances where justice is to be done seems to misunderstand the nature of what she is asked to do. ${ }^{22}$ Thus, in circumstances where the role of charitable organisations is to deliver justice, conscientious charity trustees are likely to acquire and act from the virtue of justice that is fitting to the discharge of their mandate. This means that they are likely to formulate and work through practical questions as calling for the application of principles of justice of some sort; after all, dwelling on these sorts of questions is precisely what the just person is disposed to do. Another way of putting this is to say that the just person organises her thinking about what is to be done with reference to what John Rawls calls the "role" of justice. Rawls's own account of the role of justice -which we adopt for present purposes - is that justice is engaged whenever questions about rights or distribution (or both) are in view. ${ }^{23}$ With this conception of the role of justice in mind, then, our claim is that, in a world in which it is the job of charities to deliver justice, conscientious charity trustees are likely to formulate and work through questions about rights or distribution, as opposed to questions about other topics, when deciding how to discharge their mandates.

Now there is nothing about acting from a sense of justice that necessarily precludes a person from also acting from other virtues. A person can be just some of the time, loyal some of the time, humane some of the time, and so forth. Indeed, we would suggest that a successful life is one in which each of these virtues, along with a range of others, are cultivated and expressed on occasions where they are fitting. However, there are reasons to think that charity trustees who act from a sense of justice might come to lose opportunities to cultivate and express other virtues. Charity trustees tend not to have an abundance of time and opportunity to express a multiplicity of virtues. A typical charity board might meet to set strategic and operational priorities only once a month or once a quarter. At such meetings, charity trustees may have enough time and capacity to consider only a handful of questions, perhaps even just one. They may have capacity to plan and think about priorities only in one dimension rather than in many. Under these constraints, where it is the job of charitable organisations to deliver

\footnotetext{
${ }^{21}$ Not all modes of social interaction bound up with voluntary charity are valuable: see Simone Chambers \& Jeffry Kopstein, Bad Civil Society 29 Political Theory 837 (2001). Our arguments apply only to valuable modes of social interaction.

${ }^{22}$ This assumes that justice is to be done. In some cases, an agent properly acts from virtues other than justice precisely because she has correctly determined that, all things considered, justice is not to be done. The judge who exercises mercy is an example. On mercy, see John Tasioulas, Mercy 103 Proceedings of the Aristotelian Society $101(2003)$.

${ }^{23}$ See for example the remark that "the distinctive role of conceptions of justice is to specify basic rights and duties and to determine the appropriate distributive shares" (Rawls, A Theory of Justice, supra note 16, at 6).
} 
justice, conscientious charity trustees may find that they are only ever able to think about and decide the sorts of questions about rights and distribution that the just person tends to worry over. Other virtues that they might otherwise have nurtured and manifested in action risk being crowded out. We think that there is a certain kind of moral loss associated with such a state of affairs. It is not a loss in the sense that the charity sector might generate fewer good outcomes for people; it is, rather, a loss in the sense that trustees' own moral development might be frustrated by their efforts to express virtue in action in their charity work. We return to this point below.

Where the state takes on the burden of delivering justice, the charity sector need not do so, and to this extent conditions are forestalled under which conscientious charity trustees are likely to feel the need to act from a sense of justice. When charity trustees know that the state has the business of delivering justice in hand, they can rest assured that it is not their job to do so. To the extent that the state delivery of justice has this forestalling effect, it helps to ensure that the virtue of justice does not crowd out other virtues and thereby interfere with the plurality of valuable modes of association and interaction that have long flourished within the charity sector. Charity trustees may use their limited time and resources to worry over the range of matters other than justice with which they have traditionally excelled at dealing.

An example might help to illustrate. Consider the trustees of an independent school that is registered as a charity. The school runs a specialist music programme for talented children. In a world where the state discharges the burden of achieving justice in the provision of school education to children from the full range of socio-economic backgrounds, the trustees of this school are free to act in a public-spirited way in prioritising their music programme. They need not worry that their commitment of scarce resources to that programme limits their capacity to provide bursary assistance to children from disadvantaged families. But in a world where the state fails to deliver justice in the provision of school education, or expects the charity sector to perform that work, the trustees of this independent school might come to worry over questions of access and inclusion. In doing so, they might suppress or just neglect their publicspirited desire to run a flourishing music programme and instead cultivate and express their sense of justice. The music programme might suffer as a result if resources are re-allocated, for example to fund bursaries. We think this may be of concern in itself. But for present purposes our concern lies elsewhere: whether or not the music programme suffers, the trustees' moral development might be influenced in a way that should cause us to pause and reflect. ${ }^{24}$

It might be argued that the extent to which crowding out in fact happens along the lines we have just discussed cannot be known in the absence of empirical evidence demonstrating this. Without such evidence, it might be objected that our position amounts to little more than moral-psychological speculation. To this objection, we would offer two responses. ${ }^{25}$ First, there is some modest evidence suggesting trustee behaviour consistent with a crowding out

\footnotetext{
${ }^{24}$ The example of the independent school with a specialist music programme was discussed by the Upper Tribunal for England and Wales in the case of $R$ (Independent Schools Council) $v$ Charity Commission for England and Wales [2012] 2 WLR 100. There, the Tribunal stated that as a matter of English law a charity cannot exclude the poor, and then sought to work out the implications of this rule for independent schools that charge high fees. The Tribunal considered that a school with a specialist music programme might be justified in providing less bursary assistance to poor children than a school without such a programme: at [258].

${ }^{25} \mathrm{We}$ thank an anonymous reviewer for helping us to appreciate the importance of this point.
} 
effect from one jurisdiction (England and Wales) in which charities have, in recent years, been required to pursue justice to a greater degree than in the past ${ }^{26}$. And secondly, even if there is only limited evidence of a crowding out effect, there is plenty of evidence that charities are, in their behaviour, highly sensitive and responsive to external pressures, particularly that of needing to compete with other charities for donors' attention. It is in the nature of campaigning for public attention that competitors are fighting for a relatively fixed amount of public attention, given the limits of human cognitive powers. ${ }^{27}$ The Pancreatic Cancer Action example with which we started presents a rather stark example. This suggests to us that in circumstances where the state offloads onto the charity sector the burden of delivering justice, the sheer number of charitable campaigns is likely to increase. Charity trustees will strategise and prioritise accordingly, and in these conditions crowding out is likely to occur. At a more philosophical level, it is worth registering that an orthodox view in contemporary virtue ethics is that it is very difficult for any agent (individual or collective) to exercise the full set of virtues simultaneously. ${ }^{28}$ Institutional divisions of labour, such as that between charitable and governmental agency, offer one way of (in a sense) protecting different virtues from each other, by creating contexts in which single virtues can receive a more or less dedicated exercise.

It might also be argued that for the virtue of justice to crowd out other virtues in relation to charitable agency is no bad thing. After all, even if such crowding out is counted as a cost of the charitable delivery of justice, it might turn out to be a cost worth paying, all things considered. We will return to this point below. But first, we would like to consider a different sort of objection to the proposition that the state should assume the burden of delivering justice. The objection is that, where the state takes on the burden of delivering justice, citizens may have opportunities to cultivate and express virtues other than justice in the charity sector but this will come at the cost of opportunities to cultivate and express their sense of justice. Surely acting from the virtue of justice is as important, if not more important, than acting from the variety of virtues associated with the charity sector?

This objection assumes that the state's delivery of justice is inconsistent with citizens acting from a sense of justice, most likely because that delivery depends on techniques of coercion and administration rather than voluntarism. But this assumption need not be made. Indeed, we reject it. We believe that the pursuit of justice by citizens is best enacted against a background of the right coercive institutions. We find no contradiction in the idea that states and their citizens can pursue justice together, harmoniously. A (just) coercive and administrative state is not thereby an authoritarian state. ${ }^{29}$ The pursuit of justice by the state

\footnotetext{
${ }^{26}$ See Debra Morris, Paying the Piper: The "Contract Culture" as Dependency Culture for Charities? in The Voluntary Sector, the State and the Law 123 (D Morris ed, 2000) 123; Gareth Morgan et al The Public Benefit Requirement for Charities in England and Wales: A Qualitative Study of its Impact 15 The Charity Law and Practice Review 107 (2013).

${ }^{27}$ We borrow this observation from Thomas Christiano, who makes a similar point about political campaigning in Money in Politics in The Oxford Handbook of Political Philosophy 241 (David Estlund ed, 2012).

${ }^{28}$ The possibility of simultaneous exercise is associated with an idea sometimes called the 'unity of the virtues'. We can't engage fully with the debate about this idea here, except to point to influential discussions laying out reasons to reject it: see Susan Wolf, Moral Psychology and the Unity of the Virtues 20 Ratio 145 (2007) and Gopal Sreenivasen, Disunity of Virtue 13 The Journal of Ethics 195 (2009).

${ }^{29}$ This point can be reinforced by noting that taxation need not be a very intrusive form of coercion. See Jeremy Waldron, Welfare and the Images of Charity 36 Philosophical Quarterly 463 (1986). Indeed, we find it implausible that the intuitive idea of authoritarianism has much to do with whether taxes are especially high or
} 
leaves citizens much space to orient their choices to their disposition to pursue justice. For example, citizens can still run for office, engage in (even fund) political campaigning, seek employment in a government department, and exercise choice at the ballot box. And the state institutions designed to enable the pursuit of justice can become attractive places for citizens to pursue careers based on this disposition - they just cannot function well as institutions relying on individuals' dispositions alone, and need some support from tax revenues and the administrative implementation of collective decisions. Even citizens who choose not to become politically active or work in public service still exercise their sense of justice in a negative sense, by not seeking to subvert the state's pursuit of justice, e.g. through tax evasion. It bears emphasising that the state will be able to use coercive and administrative powers much more effectively, and with greater stability, when most citizens cooperate in ways guided by moral rather than merely prudential feelings. ${ }^{30}$ This partly accounts for John Rawls's claim that citizens have what he called a "natural duty" to both support and comply with just institutions. ${ }^{31}$ Once in place, properly designed institutions can then further reinforce citizens' sense of justice. ${ }^{32}$ We accept that the coercive and administrative pursuit of justice by the state will influence and even constrain precisely how citizens can act on their disposition to pursue justice. But it certainly need not suppress or degrade such dispositions.

Indeed, we think the moral significance of the crowding out effect to which we have referred may reveal a connection between our point about the proper role of the charity sector, and concerns about the openness of state institutions to forms of political participation. It is likely that citizens possessing a sense of justice will try to act on this disposition through some set of institutions that they can find. We suspect that the increasing tendency for the pursuit of justice to occur through charitable institutions is causally related to the increasing difficulty facing the attempts of regular citizens to act from the virtue of justice through more formal channels of democratic participation. The sad fact about contemporary politics in modern western democracies is that political influence is increasingly held by a privileged few. Individual voters have less choice at the ballot box than they used to, and less ability to run for office, given the financial obstacles involved. The experience of political participation for most citizens is now increasingly reduced to what Joshua Cohen has described as the role of "audience" rather than "content-providers". ${ }^{33}$ We lack space to say anything detailed about this, so we'll fall back on a metaphor: Our talk of the crowding out effect in the charity sector might be modified so as to talk more of the migration or even 'refugee-status' of individuals'

gathered in a fashion that sticks to the rules. Instead, authoritarianism is more a matter of an absence of rule of law, poor separation of powers, draconian punishments, and suppression of political liberties. While these factors are all about ways in which states can coerce citizens, they are not specifically related to the sort of coercion associated with fiscal policy (including charity law).

${ }^{30}$ John Rawls, Political Liberalism (1993), at 48-54.

${ }^{31}$ Rawls, A Theory of Justice, supra note 16, at 311.

${ }^{32}$ Rawls argues that a sense of justice will become more stable when the "principles [of justice] are embodied in the basic structure of society" (ibid, at 119). The pursuit of justice through institutional and legal forms helps reinforce the acquisition of a sense of justice, partly because of the assurance that each citizen is given as to the impact of these principles on other people's lives. For more on the role of institutions in promoting a shared sense (or "ethos") of justice among citizens, see Joshua Cohen, Taking People as They Are? 30 Philosophy \& Public Affairs (2001). Compare GA Cohen, Rescuing Justice and Equality (2008), at 377-381.

33 Joshua Cohen, Money, Politics, and Political Equality, in Fact and Value: Essays in Metaphysics and Ethics for Judith Jarvis Thomson 47 (R Stalnaker Byrne and R Wedgwood eds., 2001). 
senses of justice, which have been forced out of their traditional home (political participation) into an environment (charitable participation) where their flourishing may entail costs paid at the expense of other virtues.

It is worth emphasizing, however, that citizens' power to influence government action through voting will be constrained, in a relevantly problematic way, even under ideal conditions. This is due to the basic difficulty of designing an electoral system that doesn't grant disproportionate influence to a small body of 'swing' voters whom legislators in any standard electoral system need to work especially hard to please. As Miranda Perry Fleischer has pointed out, "charitable tax subsidies allow taxpayers with tastes not reflected in the initial legislative process to redirect part of the funds otherwise flowing to the federal fisc through their preferred public projects". ${ }^{34}$ As Fleischer explains, any tendency for fiscal policy to favour the preferences of the median voter means that the wider citizenry stand to suffer from underproduction of goods other than those that the median voter also wants. The charity sector is, in effect, a way-around for such voters to ensure that, in effect, government spending is still directed at their preferred goods: Making a tax-deductible donation is, in effect, analogous to having one's taxes redirected towards the beneficiary of the donation. While this view of charity may be motivated by concerns about government failure with respect to relation between fiscal policy and the democratic process, it offers one way of adding substance to Reich's contention that the charity sector gains its foundational justification from a tendency to "amplify" the voices of the wider citizenry in ways that promote diversity in the production of their activities. And, similarly, the view of charity as allowing citizens to effectively redirect a degree of their tax payments converges with the central idea of our positive account, namely that the charity sector exists so that a diverse body of citizens gains greater autonomy in ways that involve taking greater responsibility for decisions about how funds contribute to the production of a wide range of goods and activities, while allowing that taxation and fiscal expenditure still exist to pursue their own purposes consistent with the division of labour.

Why, exactly, is it morally attractive that people be able to cultivate virtues other than justice in their dealings in the charity sector? Indeed, it might be thought that the tendency of the charitable delivery of justice to crowd out virtues other than justice is a good thing. This sort of argument is often raised when the virtue of justice is compared with the virtue of charity, understood in the non-legal sense as the disposition to respond to human suffering wherever it is, regardless of claims of right or distributive implications. ${ }^{35}$ The virtue of charity only strikes one as demeaning and patronising if one is thinking about that virtue from the perspective of the just person. ${ }^{36}$ We will come back to this concern in the next section when we discuss other authors' attempts to grapple with this worry about a demeaning tendency of charity.

In thinking about why the argument against the charitable delivery of justice might be morally attractive, we think there is much to offer in liberal accounts of political morality that draw on the central organising value of personal autonomy. According to these accounts, people can live autonomous - in the sense of self-determining and self-realising - lives only

\footnotetext{
${ }^{34}$ Miranda Perry Fleischer, Libertarianism and the Charitable Tax Subsidies 56 Boston College Law Review 1345 (2015), at 1349-1352.

${ }^{35}$ Gardner, supra $\mathrm{n} 15$.

${ }^{36}$ Ibid.
} 
where certain social conditions obtain. ${ }^{37}$ Among these conditions is the existence of a sufficient range of options from which to choose in forging a path through life. In any society, the sufficiency of such options will be a complex matter, responding to a range of considerations including history, tradition, and the political, economic and cultural composition of the society in question. In all cases, though, a significant diversity of options is necessary if people are to have a sufficient range of options to choose from. Moreover, and importantly for present purposes, the diversity in options that must exist if the conditions of autonomy are to obtain extends not only to diversity in goals and projects that might be pursued, but also to diversity in modes of social interaction by which people engage with their goals and projects. Many valuable aims and life paths would be thwarted, for example, in a world in which we did not form friendships, or maintain distinctions between trusting and other relationships, or have ways to be loyal to an organisation or cause. The same would be true of a world in which our only moral dealings took place in the sphere of justice. ${ }^{38}$ In particular, a world in which charity trustees were not charitable, or public-spirited, or humane, or merciful, because they made choices and acted only from a disposition to pursue justice, would be missing something of civic importance. And this would be so even if the delivery of justice by charitable organisations generated the same good outcomes as pursuing other goals through other virtues. $^{39}$

None of this is to suggest that a sufficiency of options could not be maintained in a world where the charity sector delivered justice, or that people could not live self-determining lives except where they were able to cultivate and express a range of virtues other than justice in the charity sector. Much would depend on individual and social conditions having nothing to do with voluntary charity. For example, even if citizens were unable to act from loyalty in their charitable activity, they might remain able to do so substantially in their families and friendship networks. Our purpose here is simply to point out that diversity in modes of social interaction is important to the conditions of autonomy and that any diminution in that diversity is, all else being equal, a matter for regret, given the value of autonomy. To our minds, the potential for such diminution to occur where charitable organisations are tasked with the delivery of justice is enough to ground an argument against charities being so tasked, even if it is not a conclusive argument. And even if there is no necessary connection between the charity sector and acting from certain virtues - even acts of charity can be successfully carried out in the family sphere, for example - we think that the historical and continuing association of the charity sector with a plurality of modes of free association and interaction strengthens the argument we present here. To put the point of this section a little differently, the case for a charity sector represents a significant pro tanto reason for maintaining conditions in which that sector is free to facilitate the pursuit of a diverse range of ends according to the preferences of autonomous citizens as participants and donors, and not held hostage to the requirement that justice be pursued somehow or other. Eventually, we will offer some concessive thoughts about the limits of any such pro tanto foundation, drawing on ideas about the need for charity to pick

\footnotetext{
${ }^{37}$ Joseph Raz, The Morality of Freedom (1986).

${ }^{38}$ Michael J Sandel, Liberalism and the Limits of Justice ( $2^{\text {nd }}$ ed., 1998) at Ch.1).

${ }^{39}$ If delivering justice through the charity sector generated better outcomes than pursuing other goals through other virtues, then matters would be different. But even then, a diminution in the modes of social interaction pursued via the charity sector would appropriately be counted as a moral loss.
} 
up the slack given government failure with respect to the pursuit of justice. But for now, we take ourselves to have offered an argument that is an important component of the overall case for thinking that delivering justice is, at least primarily, the business of the state.

\section{Applications of Pluralism to Other Arguments about the Division of Labour}

The last section presented a theoretical case for preferring that justice be pursued largely by the state, by giving reasons for why the charity sector can facilitate the pursuit of rather different goals relating to the cultivation of autonomy and non-justice virtues, as embodied by pluralism. The plausibility of this sort of pluralism can be enhanced by connecting it with philosophical concerns advanced by others who have also argued for a division of labour where tax-funded institutions are assigned primary responsibility for the pursuit of justice. In this final section we'll address a variety of views where we think pluralism can accommodate and even advance some of the insights made. We will also take the opportunity to advance some more independent criticisms of the views surveyed, while seeking to improve their insights with the help of our own positive account.

\section{Deriving a division of labour from a theory of legitimate authority}

Will Kymlicka has claimed that "charity is a second best response to injustice". ${ }^{40}$ This view relies heavily on an account of what the state is for, or, more precisely, how the institutions of government gain their legitimate authority. According to Kymlicka, the point (in short), is that state institutions become illegitimate if they do not secure justice. So, a society in which the pursuit of justice is left to voluntary charity is one in which "individuals have no moral obligation to comply with [the state's] institutions". In other words, justice should not be left to charity because, were this to happen, the state would be failing in its major justifying function. The reverse, however, is not true - charity is not necessarily defective if it leaves the pursuit of justice to the state. Kymlicka's is one way of arguing for a division of labour that falls more heavily on the state. Here, Kymlicka argues from some conception of the moral foundations of the institutions of government, rather than from a conception of the moral foundations of the institution of charity. This is fine as far as it goes, but we feel that something is being left out of the conversation if charity's foundations are not also considered.

What exactly explains why charity would not be defective if it left the pursuit of justice to the state? Without some argument for this claim, Kymlicka's position risks simply begging the question: Why can't an opponent of coercive taxation simply protest that their moral objections to forcing people to pay for the relief of the deprivations of others is, by itself, reason to doubt that citizens ought to have a moral obligation to comply with state institutions seeking to bring about such ends? This needn't just be scepticism about the legitimate authority of coercive state institutions. ${ }^{41}$ One might simply think that there are problems with assuming that

\footnotetext{
${ }^{40}$ Kymlicka, supra note 17 , at 94 .

${ }^{41}$ Though it is notable that libertarian views, so long as they rely mainly on an opposition to coercion as an infringement of property rights, may struggle to avoid rejecting all state coercion and collapse into anarchism. On this see Barbara Fried, Does Nozick have a Theory of Property Rights?, in The Cambridge Companion to Nozick's Anarchy, State and Utopia 230 (R Barder \& J Meadowcroft eds., 2011).
} 
states have legitimacy when it comes to pursuing justice and then using this assumption to highlight an apparent lack of legitimacy when charity goes about pursuing the same ends. Admittedly, Kymlicka is applying a fairly mainstream view about the foundations of a legitimate state, one that he attributes to both John Rawls and John Stuart Mill. But such accounts have always been contentious. Why not think that the state's justifying function is something else, e.g. that it gains its legitimacy from solving coordination problems and providing security? On this view, a charity sector geared towards pursuing justice would not be acting in ways that got the state off the hook.

In sum, one has to already accept that the state should take primary responsibility for pursuing justice in order to conclude that charity should not. And this risks being a circular argument about the division of labour. We say 'risks' because there may after all be ways of defending the view that state legitimacy is, after all, grounded in a capacity to secure justice and not (for example) just to solve other problems associated with conditions of anarchy. But Kymlicka's position remains one on which a positive account of charity is left out of things, and is the worse for it. And again pluralism can provide other reasons why charity is a "second best" remedy for injustice on grounds that there is an opportunity cost associated with relying on the charity sector to do this kind of work. This opportunity cost is, as we have explained, the loss of the various activities that cultivate autonomy and virtue in citizens left able to pursue activities whose viability depends on, or is enhanced by, the protections afforded by legal charitable status. Charities also tend to be less able than the state to respond correctively to unforeseen side-effects of the goals they pursue, which might be an independent reason to consider them a "second best" mechanism. ${ }^{42}$ Really we are making a methodological point here: Any claim about the state's legitimate role, when used to make a further claim about the division of labour between the state and the charity sector, will be more plausible if accompanied by a complementary claim about charity's legitimate role as being something distinct. As we said at the outset, there is a problem with approaching the question of the division of labour as if no positive account of charity can prove useful. Proceeding without such an account is precisely what might put otherwise promising arguments, such as Kymlicka's, at risk of circularity.

\section{Status inequality and burdened donors}

Another influential concern is that charities promote anti-egalitarian relationships between donors and beneficiaries, where promotion of such relationships can be avoided when taxfunded state institutions pursue similar goals. If this is right, then it's another reason for resolving the division of labour question largely in favour of leaving the pursuit of morally urgent objectives to the state. A classic version of this view can be found in various democratic socialist writings from the early $20^{\text {th }}$ century. Clement Attlee, for example, wrote that "charity is always apt to be accompanied by a certain complacence and condescension on the part of the benefactor, and by an expectation of gratitude from the recipient which cuts at the root of all true friendliness" ${ }^{43}$ In a recent discussion of the division of labour from an egalitarian

42 This point is made more fully by Cordelli, The Institutional Division, supra note 3, at 136 .

${ }^{43}$ Clement Attlee, The Social Worker (1920). 
perspective, Veronique Munoz-Darde and M.G.F. Martin discuss this view at greater length. The root of the objection, as they see it, is that "charities are a form of vicarious begging". 44 This makes sense of Attlee-type worries about the recipients of charity being induced to represent themselves as social inferiors rather than the bearers of legitimate entitlements. ${ }^{45}$ They are, however, sceptical about the classical version of the view for two reasons. First, charitable organizations typically keep donors and beneficiaries physically separate from each other. This greatly reduces the risk of a beneficiary needing to represent themselves to someone as their inferior. Charities are, in practice, often very good at interacting with beneficiaries in ways that are sensitive and respectful. Second, there is the fact that plenty of charities produce "benefits to individuals which we don't tend to think of as humiliating to receive". MunozDarde \& Martin offer the example of an academic research grant (many of which are, of course, provided by charitable foundations).

Munoz-Darde \& Martin go on to propose that charity resembles begging in a different way. Here the idea is that "effective begging requires that the donor be manipulated in their emotional responses: moved into a position of feeling distress or guilt such that the act of giving will lessen the distress felt". ${ }^{46}$ The general point is that, because charities rely on voluntary donations in ways that tax-funded institutions do not, they must do more than simply "disseminate information" about their cause, but must instead "stir the emotions". While this may not be problematic on a small scale, Munoz-Darde \& Martin argue that an increasing reliance on the charity sector to deliver goods and services will only mean an increase in the burdening of donors through "continuous and repeated demands and charities" is, overall, of comparable moral concern to the burdens (such as they $a^{47}{ }^{47}$ of being burdened by coercive taxation.

We think that Munoz-Darde \& Martin are basically right to highlight effects on donors as a reason to prefer tax-funded institutions over charities with respect to the provision of morally urgent goods and services. But we think their point can be put more plausibly with greater reference to pluralism of the sort we've defended. We want to note, first, that we are not wholly persuaded by Munoz-Darde \& Martin's claim that the classic anti-begging argument is inferior to their donor-centric development of it. Their counter-example of the academic research grant gets its force from its failure to involve humiliation or subordination of the recipient. ${ }^{48}$ But we are sceptical as to whether the emotional manipulation of donors is

\footnotetext{
44 Veronique Munoz-Darde \& MGF Martin, M, Beggar Your Neighbour (Or Why You Do Want to Pay Your Taxes) in Taxation: Philosophical Perspectives 124 (M O’Neill \& S Orr eds., 2018), at 127).

${ }^{45}$ In this way, the classic objection falls squarely within what has more recently become known as 'relational egalitarianism' in political philosophy. This view involves a conception of justice on which equality is construed in terms of the character of interpersonal (or intergroup) relationships and interactions, not fundamentally in terms of equal distributions of material things. For a summary see Elizabeth Anderson, Equality, in The Oxford Handbook of Political Philosophy 40 (D Estlind ed., 2012).

${ }^{46}$ Munoz-Darde \& Martin, M, supra note 44, at 134.

${ }^{47}$ Although we will not push this point, there is a case for regarding coercive taxation as rather low in terms of the psychological (as opposed to sheer financial) burden it imposes. This is because, for many taxpayers, the act is not of surrendering property or wealth but rather what Jeremy Waldron (supra note 29) has described as "forbearance", as taxes are simply withheld prior to the receipt of income.

48 This may be because the whole exercise of competing for grants is about presenting oneself as especially meritorious. As such, receiving a grant signals academic merit, at least relative to the criteria of the awarding organization. In addition, research grants are pursued in response to an explicit request for applications from donor organisations. So, there are at least two apparent disanalogies with street begging. This might further guide efforts
} 
sufficiently general either. Consider, for example, a charitable campaign that sought to motivate donors to give money to fund an opera or museum. It's hard to see this working by way of emotional manipulation of a burdensome sort. This suggests that the problem with "continuous and repeated demands" can't be as narrow as the burden of having to feel guilt and distress about the presence of a cause whose relief one is being asked to fund. Some sort of broader account of the moral cost of increased requests for donations is required.

We agree with Munoz-Darde \& Martin's suggestion that an increased reliance on charity creates a competitive situation in which different organizations have to find ways to get ahead of each other in fundraising. It is absolutely right to suggest that, as tax-funded institutions are done away with, we face a scenario in which "there are more needs to be met than there are likely to be acts of spontaneous charity by donors". Charities, however, will likely attempt other means of soliciting funds than simply making donors feel guilty. Here it is worth recalling the case of Pancreatic Cancer Action. Whatever the intentions of the campaigners (which we assume to be benevolent), the perception was very much that the style of communication attempted to downplay the significance of breast cancer and to present it as 'less worthy' of a donor's support. The cost of institutionalized begging is perhaps no more than the costs that occur by way of competition that ultimately tends towards a wasteful, zerosum structure.

The general point we wish to stress is this: Once there is a presumption that charities can appropriately take on the objective of addressing society's most morally urgent problems, there is a risk that they need to demonstrate their credentials to donors by making clear the moral urgency of their cause. Whether this is done by making donors feel guilty about the cause, or by downplaying alternative causes, is another matter. But what is very likely is that morally non-urgent activities will simply struggle to compete. This recalls our earlier foundational point made in the last section about the risks of crowding out within the charity sector: If charitable campaigning is about organizations' communicating their ability to 'do the most good', then there is little hope for charities whose goals are not about relieving great injustice or deprivation. Instead, we risk a 'winner takes all' market in which some small number of charities flourish due to an ability to communicate the urgency of their cause, while many smaller causes fall by the wayside. More generally, the acceptance of charity as a vehicle for simply doing good runs counter to having a charity sector geared towards the pursuit of a wide range of diverse goals at once, creating opportunities for citizens to take on any of a wide variety of activities conducive to developing their own autonomy. This preserves the parallel with begging in the following way: Begging basically involves an act of requesting funds by appealing to considerations of urgency or desperation. But a charity sector, under pluralism, is supposed to facilitate something different: A range of activities whose value is not in their relieving urgent need but in their presenting a diverse range of options, made possible under the assurance that the state is taking responsibility for addressing the bigger problems of deprivation and injustice. After all, when a cause is not especially morally urgent, there is a sense in which begging is not possible just because there is nothing dramatic to communicate.

to distinguish conditions under which charitable donation involves representations of inferiority in the recipient from cases where it is designed so as not to do so. 
There is no analogue of the Pancreatic Cancer Action ad for charities that exist for the sake of pluralism alone.

\section{Plutocracy}

It has been argued that charities undermine conditions of democracy. Empirically, some scholars report evidence that charitable organizations shy away from engaging with social justice, even when their goals are concerned with alleviating poverty and inequality. ${ }^{49} \mathrm{~A}$ more philosophical worry is that there is something anti-democratic about the way in which the charity sector, when allowed to become a mechanism for political influence, ends up distributing such influence very unequally due to the sheer fact that it disproportionately empowers citizens with the most money, without appropriate checks on such power. ${ }^{50}$

Although these concerns have force, there is nothing especially objectionable about political influence being exercised in any way through the charity sector. There are plenty of overtly political charities that attract praise, such as various charities aimed at providing legal advice and representation to parties who cannot afford it, or which highlight government failures in the criminal justice system. Many charities will lobby governments as part of their efforts to bring about legislative outcomes more favourable to their cause. Indeed, it is hard to imagine how a charity can really endorse a cause without thereby taking some view about how the law ought to be changed. Now, we are not trying to suggest that the charity sector should create space for political activity without qualification, and indeed charity law typically includes rules restricting the extent to which charities may engage in politics and remain charities. The traditional position within charity law is that an organisation whose primary purpose is political cannot be a charity. This traditional position was worked out in case law over many years, including a celebrated case in which an English judge declared that Amnesty International was not a charity because of its political orientation. ${ }^{51}$ Charity law's traditional scepticism about charities with political purposes has been replaced by a more accommodating approach in some jurisdictions but even in those jurisdictions, it remains difficult for organisations to form for political purposes and satisfy the legal requirements to be a charity. ${ }^{52}$

There is a lot of substance to the plutocracy objection, properly understood. But in order to appreciate the force of its substance, once again we need to work with a positive conception of what charity is for. And again, this is in order to identify what is lost when the charity sector begins to exhibit features that motivate the plutocracy objection. Really, the plutocracy worry is about what tends to happen when a single foundation or donor has great wealth and not about the political or non-political nature of their objectives, whatever 'political' might mean in this context. It is worth noting that worries about wealth agents and institutions might be 'sector

\footnotetext{
${ }^{49}$ Balihar Sanghera \& Kate Bradley, Social Justice, Liberalism, and Philanthropy: The Tensions and Limitations of British Foundations in New Philanthropy and Social Justice 175 (B Morvaridi ed., 2015).

${ }^{50}$ Here we draw on writings such as ibid; Reich, supra note 10, at Ch.4; Saunders-Hastings, supra note 11.

${ }^{51}$ McGovern v Attorney-General [1982] 1 Ch 321 (Slade J). See also Bowman v Secular Society Limited [1917] AC 406, 442 (Lord Parker).

${ }^{52}$ For an excellent example of the difficulties, see the decision of the Supreme Court of New Zealand in In re Greenpeace of New Zealand Incorporated [2015] I NZLR 169, and the subsequent decision of Simon France J of the High Court of New Zealand in In re Family First New Zealand [2018] NZHC 2273, overturned on appeal by the New Zealand Court of Appeal in Family First New Zealand v Attorney-General [2020] NZCA 366.
} 
independent': Disproportionate influence can occur outside of the charity sector, as evidenced by parallel worries about political office becoming inaccessible to parties who do not possess sufficient wealth, and by corporate and media entities being in a position to intimidate politicians. In large part the worry is not about what kind of activities any foundation or donor engages in, but about charitable activity becoming concentrated at the expense of remaining diversified.

Some of this can be pointed out without the help of pluralism. For example, wealthy donors or large foundations are in a much stronger position than small donors to attach conditions to the gifts they give out. This sort of complaint has been levelled at the Bill and Melinda Gates Foundation, and also at Mark Zuckerberg, both concerning influence of their donations over K-12 schooling in the USA. This is largely a concern about accountability (or lack thereof) and the role of agents who are shaping an institution without possessing much relevant expertise. But this can't be the whole point. As Robert Reich has pointed out, lack of accountability is not necessarily a universally bad thing: Charitable organizations can often achieve goals that the state struggles to pursue, particularly goals whose pursuit is subject to long time-horizons and delayed benefits, both of which limit their pursuit by legislators who have to seek re-election.

Pluralism helps give the plutocracy worry some substance in the following way: The charitable sector, we would argue, is perfectly legitimate as a sector that can house political influence. The problem is when this influence is concentrated into a relatively small set of agents, who (in keeping with their size) end up pursuing a narrow range of goals. Further, there is the problem that large foundations risk behaving more like firms and less like voluntary associations in which people devote their spare time to pursuing a shared end. ${ }^{53}$ Again, a relatively small set of wealthy, dominant organizations stand to crowd out the smaller organizations who will struggle to compete. Elite philanthropy is therefore problematic not necessarily because it involves political influence in the wrong place, but because it displaces activities that depend on a charity sector for their viability, but whose viability is further dependent on the sector being geared towards housing a relatively large set of relatively small organizations. Pluralism and the plutocracy objection converge, therefore, insofar as the worry is still one about the activities of 'big philanthropy', but where the moral cost of these activities lies not wholly in the nature and influence of such activities, but also in the cost in terms of undermining the charity sector's foundational potential.

\section{Conclusion}

We have defended a positive account of the moral foundations of the charity sector, construed as a legal phenomenon. The purpose of this account is to fill an important gap in ongoing debates about the appropriate division of labour between state institutions (especially those relating to fiscal policy) and charitable organizations that facilitate the pursuit of goals through voluntary participation and donation. Very generally, this account is intended to improve on the unsatisfactory construal of charitable organizations as little more than mechanisms for

\footnotetext{
${ }^{53}$ See for example Reich's anecdotal evidence concerning the Open Society Foundation, set up by George Soros (Reich, supra note 10, at 148).
} 
"doing good" that might step in when the state fails to do so. More specifically, we have begun to apply our account to some of the more pertinent claims about the division of labour itself.

Any view about the moral foundations of charity needs to work in concert with parallel views about the moral foundations of state coercion as an alternative mechanism for pursuing goals that could in principle be pursued by charity instead. We have aimed to stay largely neutral here on any view about the limits of state legitimacy and how these bear on the proper scope of fiscal policy with respect to the production of goods. We recognize that the view we've provided is defeasible in at least two general respects: The proper role for charity needs to be adjusted to any independent view about what the state ideally ought to do, and, just as important, any considerations about what should happen when the state does not act in an ideal way. However, where the need for such reflection on the foundations of state power has generally been recognized, there is less of a history of taking the foundations of charity comparably seriously. And as a general proposition it seems right to consider those foundations in light of the ideal division of labour between the state and the charity sector, before bringing into the picture the need for compromises and work-arounds in the non-ideal world of day to day politics. Of course, what's ultimately desired is some account of charity that provides guidance in a non-ideal world where government failures with respect to the pursuit of justice are common. But any account of how the charity sector ought to set priorities in picking up the slack needs to be informed by some account of what stands to be given up if charity is to depart from its ideal function. Rather than simply encourage the view that charity can and should do good work wherever there's good work to be done, ${ }^{54}$ we want to promote the view that the agency of the charity sector is just as deserving of an ideal account as the agency of the state or any other sector. Without any such account, charity risks becoming a slave to failings elsewhere. It is on this dimension that we have tried to make progress.

\footnotetext{
${ }^{54}$ Here we are converging slightly with some of the efforts to push back against some views about merely evaluating charity according to how much good it can do. See supra note 5.
} 


\section{University Library}

\section{- M M N E R VA A gateway to Melbourne's research publications}

Minerva Access is the Institutional Repository of The University of Melbourne

Author/s:

Halliday, D;Harding, M

Title:

KEEPING JUSTICE (LARGELY) OUT OF CHARITY: PLURALISM AND THE DIVISION OF LABOR BETWEEN CHARITABLE ORGANIZATIONS AND THE STATE

Date:

2021

Citation:

Halliday, D. \& Harding, M. (2021). KEEPING JUSTICE (LARGELY) OUT OF CHARITY: PLURALISM AND THE DIVISION OF LABOR BETWEEN CHARITABLE ORGANIZATIONS AND THE STATE. Legal Theory, 26 (4), pp.1-24. https://doi.org/10.1017/ s1352325220000233.

Persistent Link:

http://hdl.handle.net/11343/258825 